\title{
HACKLEY $V$. JOHNSON: THE FEDERAL EMPLOYEE'S RIGHT TO TRIAL DE NOVO REVIEW OF CIVIL SERVICE DISCRIMINATION DETERMINATIONS
}

Courts have long recognized that a private sector employee who is dissatisfied with the factfinding or the conciliation procedures of the Equal Employment Opportunity Commission (EEOC) in a Title $\mathrm{VII}^{1}$ action can press his claim in federal district court and is entitled to discovery and to new factfinding even if it is duplicative of the work of the EEOC. ${ }^{2}$ In Hackley $v$. Johnson, ${ }^{3}$ however, the District Court for the District of Columbia held that a federal employee who had had a seven-day factfinding hearing on his employment discrimination claim before the Civil Service Commission (CSC) (the counterpart to the EEOC for federal employees ${ }^{4}$ was entitled only to review by the district court based on the record established at the CSC hearing. He could not have a trial de novo. ${ }^{5}$ The issue presented in Hackley is of twofold importance.

First, it may be of great importance to plaintiffs that they have the opportunity in a trial de novo to frame their action themselves and to use fully the discovery allowed under the Federal Rules of Civil Procedure, rather than relying on the CSC's record, which is developed with less employee control ${ }^{6}$ and without the benefits of discovery. ${ }^{7}$ Second, provision of a possi-

${ }^{1} 42$ U.S.C. $\$ \S 2000 \mathrm{e}$ et seq. (1970), as amended (Supp. II, 1972).

${ }^{2}$ See, e.g., McDonnell Douglas Corp. v. Green, 411 U.S. 792 (1973); Cox v. United States Gypsum Co., 284 F. Supp. 74 (N.D. Ind. 1968), aff'd as modified, 409 F.2d 289 (7th Cir. 1969).

${ }^{3} 360$ F. Supp. 1247 (D.D.C. 1973), appeal docketed, No. 73-2072, D.C. Circuit, Sept. 7,1973 . The appeal has not yet been scheduled for argument.

${ }^{4}$ The Givil Service Commission is the counterpart agency to the EEOC in that it is the agency which has general responsibility to guard against employment discrimination in the public sector. 42 U.S.C. $\$ 2000 \mathrm{e}-16$ (b) (Supp. II, 1972). It generally oversees the employment policies of the various agencies by requiring annual reports, assisting in the development of affirmative action programs, and investigating complaints of public employees after an initial investigation by the agency involved. It differs from the EEOC in two major respects: an investigation by the CSC is not a procedural prerequisite to the institution of suit in federal court by an employee, while an initial investigation by the EEOC is; and the CSC has been granted coercive power by Congress, while the EEOC has no coercive power of its own, although it can institute a federal suit. Compare 42 U.S.C. $\S \S 2000 \mathrm{e}-16(\mathrm{a})$-(c) (Supp. II, 1972), with 42 U.S.C. \$§ $2000 \mathrm{e}-4$ to -5 (1970), as amended, 42 U.S.C. $\$ \S 2000 \mathrm{e}-4$ to -5 (Supp. II, 1972).

$5360 \mathrm{~F}$. Supp. at 1252.

${ }^{6}$ For a discussion of this point, see text accompanying note 34 infra.

${ }^{7}$ See FED. R. Civ. P. 26-37. 
ble trial de novo could have a profound impact on federal docket congestion. The district court in Hackley pointed out that its docket at the time of the decision contained nineteen individual and class actions presenting this issue. ${ }^{8}$ If no trial de novo were required, these actions could be dealt with more expeditiously.

A few other jurisdictions have grappled with the question of de novo hearings in district court after CSC factfinding and decision. They have not been uniform in their treatment ${ }^{9}$ and a number of appeals are currently pending. ${ }^{10}$ Because of the force of expertise behind decisions by the Court of Appeals for the District of Columbia Circuit in the area of administrative law, it is likely that the decision in Hackley will be given great weight in other jurisdictions.

This Comment will show that the statutory language and the applicable legislative history is at best ambiguous whether a trial de novo is required or available when a federal employee, dissatisfied with a CSC determination, brings suit in district court. However, the need to avoid the unjust results that could be caused by conflicts of interest within the executive branch requires a policy matter that the courts have the capacity to order a trial de novo.

\section{The District Court's Rationale for Denying a Trial De Novo}

The appellant in Hackley is a black investigator with the federal Veterans Administration. On November 10, 1970, Mr. Hackley became eligible for, but was denied, promotion. He alleged that this denial reflected racial discrimination and lodged an initial complaint with the Veterans Administration. The VA determined that he had been subjected to racial discrimination, but declined to promote him. He then obtained a hearing before the CSC, which lasted seven days. The appeals examiner concluded that racial discrimination had not prevented his promotion. The VA adopted the findings of the appeals examiner and denied relief. Hackley exhausted his administrative remedy

${ }^{8} 360$ F. Supp. at 1249 n.2.

${ }^{9}$ Compare Reynolds v. Wise, 375 F. Supp. 145 (N.D. Tex. 1974); Henderson v. Defense Contract Admin. Serv. Region, 370 F. Supp. 180 (S.D.N.Y. 1973); Griffin v. United States Postal Serv., 7 CCH Emp. Prac. Dec. T 9133 (M.D. Fla. 1973) (all allowing trial de novo), with Spencer v. Schlesinger, 374 F. Supp. 840 (D.D.C. 1974); Pointer v. Sampsom, 62 F.R.D. 689 (D.D.C. 1974); Thompson v. United States Dep't of Justice, 372 F. Supp. 762 (N.D. Cal. 1974); Tomlin v. United States Air Force Medical Center, 369 F. Supp. 353 (S.D. Ohio 1974); Chandler v. Johnson, 7 CCH EMP. Prac. Dec. ף 9139 (C.D. Cal. 1973); Handy v. Gayler, 364 F. Supp. 676 (D. Md. 1973); Williams v. Mumford, $6 \mathrm{CCH}$ EMP. PRAC. DEC. I 8785 (D.D.C. 1973) (not allowing it).

${ }^{10}$ See, e.g., Franklin v. Laird, 360 F. Supp. 1247 (D.D.C. 1973) (consolidated with Hackley on appeal). 
by appealing to the CSC Board of Appeals and Review, where the VA's decision was affirmed. ${ }^{11} \mathrm{He}$ finally filed an action in federal district court seeking declaratory and injunctive relief and retroactive promotion and back pay under a theory based in part on Title VII.

The defendants moved for summary judgment based upon the facts found in the administrative record. The district court granted the motion, finding, on the basis of both legislative history and underlying policy, that Title VII does not require a trial de novo when the CSC has already undertaken a lengthy hearing. The court concluded that congressional intent was to limit aggrieved public employees to district court review on the basis of the administrative record, rather than to provide a trial de novo. ${ }^{12}$

\section{The Absence of Glear Legislative GUIDANCE}

Although the Hackley district court did not discuss the precise wording and structure of the statutory provisions granting federal jurisdiction, ${ }^{13}$ a close analysis of the language suggests that a trial de novo was intended. The Supreme Court and the lower federal courts had ruled, long before the congressional amendments, that a private sector employee was entitled to a trial de novo in federal court even though the EEOC had determined that no probable cause for the complaint existed. ${ }^{14}$ When drafting the amendments describing the federal court jurisdiction in actions involving federal employees, Congress incorporated, to the extent "applicable,"15 the sections specifically authorizing such actions by employees in the private sector. It is unclear, however, which of the private sector provisions was incorporated. For example, the "as applicable" sections might include the provision requiring the judge in a private sector action "to assign the case for hearing at the earliest practicable date.... If such a judge has not scheduled the case for trial within one hundred and twenty days that judge may appoint a master . . ." ${ }^{16}$ If so, this

${ }^{11}$ For a record of the administrative decisions, see Brief for Appellant, Hackley v. Johnson, No. 73-2072, D.C. Circuit, docketed Sept. 7, 1973 (appendix).

$12360 \mathrm{~F}$. Supp. at 1250-52.

${ }^{13}$ The court quoted most of the applicable language but did not discuss it in any detail. 360 F. Supp. at 1250.

${ }^{14}$ McDonnell Douglas Corp. v. Green, 411 U.S. 792 (1973). Accord, Robinson v. Lorillard Corp., 444 F.2d 791 (4th Cir. 1971); Beverly v. Lone Star Lead Constr. Corp., 437 F.2d 1136 (5th Cir. 1971); Flowers v. Local 6, Laborers Int'l Union, 431 F.2d 205 (7th Cir. 1970); Fekete v. U.S. Steel Corp., 424 F.2d 331 (3d Cir. 1970); Grimm v. Westinghouse Elec. Corp., 300 F. Supp. 984 (N.D. Cal. 1969).

1542 U.S.C. \$ 2000e-16(d) (Supp. II, 1972).

1642 U.S.C. $\$ 2000 \mathrm{e}-5(f)(5)$ (Supp. II, 1972) (emphasis added). 
language might imply that the district court in a federal employee case is required to develop an independent factual record.

The legislative history unfortunately does more to confuse than to elucidate the problem. Supporting trial de novo is the statement of Senator Cranston: "As with other cases brought under Title VII of the Civil Rights Act of 1964, Federal district court review would not be based on the agency and/or CSC record and would be a trial de novo." 17 This language was relied upon in Henderson v. Defense Contract Administration, ${ }^{18}$ which granted a trial de novo to a Defense Contract Administration employee who alleged racial discrimination. ${ }^{19}$ It must be noted, however, that these remarks of Senator Cranston were a correction of his earlier remarks, which may have given a different impression. ${ }^{20}$

The court in Hackley relied instead on a statement by Senator Williams $^{21}$ (and on an analysis of the proposed bill inserted in the record) to indicate that trial de novo was not intended. Senator Williams had stated: "[W]ritten expressly into the law is a provision enabling an aggrieved Federal employee to file an action in U.S. District Court for a review of the administrative proceeding record after a final order by his agency or by the Civil Service Commission."22 However, the precise meaning intended by Senator Williams is not clear, for in the same paragraph he added: "There is no reason why a Federal employee should not have the same private right of action enjoyed by individuals in the private sector . . .."23 District Court Judge Gasch in Pointer v. Sampson ${ }^{24}$ explained this apparent inconsistency by speculating that the latter remark was in reference to the proposed right of private sector employees to review of the administrative record by the Court of Appeals if cease and desist power were given to the EEOC. The power was never granted.

Given this imprecise drafting and contradictory legislative history, courts seeking to interpret the Equal Employment Opportunity Act of 1972 must look to the policies underlying the Act which do emerge clearly from the legislative history.

17118 Cong. Rec. 4929 (1972). The district court used the daily edition of the Congressional Record, 360 F. Supp. at 1252 n.7, and relied on the initial erroneous statement of Senator Cranston as support for its decision that a trial de novo was not intended by Congress.

${ }^{18} 370$ F. Supp. 180 (N.D. Tex. 1973).

${ }^{19} \mathrm{Id}$. at 184 .

${ }^{20} I d$.

21360 F. Supp. at 1251-52.

22118 Cong. Rec. 4922 (1972).

${ }^{23} \mathrm{Id}$.

${ }^{24} 62$ F.R.D. 689 (D.D.C. 1974). 


\section{The Hackley Result: Failure to Recognize the Need for a Flexible Mechanism to Police CSC Conflict of Interest}

The policy questions which appear to have been considered by Congress include: the impact of granting trial de novo on potential docket congestion; whether an initial election to pursue administrative remedies should foreclose the aggrieved federal employee from a fresh factual determination in the district court; and whether conflicts of interest within the executive branch may, upon occasion, require a trial de novo.

\section{A. The Congestion Problem}

The district court in Hackley expressed concern that a trial de novo would necessarily "duplicate much of the administrative" record and "would impose an especially heavy burden on the federal trial courts in this jurisdiction."25 This policy consideration is not persuasive for two reasons.

First, even if duplication were to result, it is certainly a burden that should be assumed by the courts, given the very high priority Congress has given Title VII cases. ${ }^{26}$ Second, it is not clear that the district court's decision in Hackley will result in a lighter docket. Public employees have a choice under Title VII to opt out of CSC review. ${ }^{27}$ Because plaintiff employees could not control the administrative investigation and would have much greater rights of discovery in federal court, it is likely that many of them will not request a hearing. This is especially true in light of the congressional finding that many employees are skeptical of the hearing's efficacy in any case. ${ }^{28}$ Thus, while the Hackley result may reduce the burden of review, it may also result in a greater number of cases being filed initially in federal court. Some percentage of these cases filed in federal court will repre-

25360 F. Supp. at 1249 (citation omitted).

${ }^{26}$ Alexander v. Gardner-Denver Co., 415 U.S. 36, 47 (1974). Newman v. Piggie Park Enterprises, Inc., 390 U.S. 400, 402 (1968).

${ }^{27} 42$ U.S.C. $\S 2000 \mathrm{e}-16$ (c) (Supp. II, 1972).

${ }^{28}$ House Comm. on Educ. and Labor, Equal Employment Opportunities ENFORCEMENT ACt OF 1971, H.R. REP. No. 92-238, 92d Cong., 1st Sess. 24 (1971) [hereinafter cited as House REPORT]:

Testimony reflected a general lack of confidence in the effectiveness of the complaint procedure on the part of Federal employees. Complainants were skeptical of the Civil Service Commission's record in obtaining just resolutions of complaints and adequate remedies. This has discouraged persons from filing complaints with the Commission for fear that it will only result in antagonizing their supervisors and impairing any hope of future advancement. 
sent suits that could have been heard and finally resolved at the CSC level but for the Hackley rule.

An affirmance of the Hackley decision might, therefore, do very little to relieve the pressures placed on federal courts by heavy dockets. There are strong incentives for plaintiffs to file Title VII actions in court rather than in the CSC, and the Hackley reasoning may only strengthen them, burdening the courts even more.

\section{B. The Election Problem}

Another policy consideration raised by Hackley is whether aggrieved federal employees should be forced to elect either a hearing before the CSC or a trial in district court. Recently the Supreme Court in Alexander v. Gardner-Denver Co. ${ }^{29}$ held that, in the private sector, an employee was entitled to have a discrimination allegation cognizable under Title VII tried de novo in federal court despite the prior submission of the claim to arbitration under a collective bargaining agreement. If the reasoning in Alexander applies to the Hackley case, it lends support to the view that a federal employee who chooses a CSC determination initially should not be foreclosed absolutely from an independent judicial determination of the facts of his case. However, it is possible that the court of appeals could distinguish Alexander from Hackley.

The petitioner in Alexander, claiming he was discharged because of his race, filed both a grievance under a collective bargaining agreement and a charge with the Colorado Civil Rights Commission. The latter was referred to the EEOC. His claim went to arbitration pursuant to the collective bargaining agreement, and the arbitrator ruled that he had been fired for cause. The EEOC subsequently determined that there was no reasonable ground for finding a Title VII violation. Petitioner then filed a Title VII action in federal district court. Summary judgment was granted against him on the basis of the binding arbitration decision. The Supreme Court held that he was entitled to a trial de novo in district court, notwithstanding the strong federal policy in favor of encouraging settlement of labor disputes through arbitration.

One objection the Supreme Court had to the arbitration procedure was that the factfinding process was not as thorough as the factfinding in a civil suit:

$[\mathrm{T}]$ he factfinding process in arbitration usually is not equivalent to judicial factfinding. The record of the arbitration proceedings is not as complete; the 
usual rules of evidence do not apply; and rights and procedures common to civil trials such as discovery, compulsory process, cross-examination, and testimony under oath, are often severely limited or unavailable. ... Indeed, it is the informality of arbitral procedure that enables it to function as an efficient, inexpensive, and expeditious means for dispute resolution. This same characteristic, however, makes arbitration a less appropriate forum for final resolution of Title VII issues than the federal courts. ${ }^{30}$

Many of these same objections apply to the factfinding procedure in the CSC hearing. The complaints examiner is not empowered to subpoena witnesses or documents. Although the examiner can request that any agency make one of its employees available as a witness, the agency has no coercive power over a former employee whose testimony is pertinent but who is no longer in the employ of the federal government. ${ }^{31}$ In addition, the hearing is more informal that that in an action in federal court, and rules of evidence are not as strictly applied. ${ }^{32}$ There is no requirement that the examiner who presides at the hearing have legal training. He must only meet "the standards of experience and training prescribed by the Commission." 33 Another important objection to reliance on the CSC factfinding record

${ }^{30} \mathrm{Id}$. at 57-58 (citations omitted).

315 C.F.R. $\$ 713.218($ e) states:

The complaints examiner shall request any agency subject to this subpart to make available as a witness at the hearing an employee requested by the complainant when he determines that the testimony of the employee is necessary. He may also request the appearance of an employee of any Federal agency whose testimony he determines is necessary to furnish information pertinent to the complaint under consideration. The complaints examiner shall give the complainant his reasons for the denial of a request for the appearance of employees as witnesses and shall insert those reasons in the record of the hearing. An agency to whom a request is made shall make its employees available as witnesses at a hearing on a complaint when requested to do so by the complaints examiner and it is not administratively impracticable to comply with the request. ...

Cf. Merrill, Procedures for Adverse Actions Against Federal Employees, 59 VA. L. REv. 196, $223(1973)$.

325 C.F.R. $\$ 713.218(\mathrm{c})(2)$ states:

The complaints examiner shall conduct the hearing so as to bring out pertinent facts, including the production of pertinent documents. Rules of evidence shall not be applied strictly, but the complaints examiner shall exclude irrelevant or unduly repetitious evidence. Information having a bearing on the complaint or employment policy or practices relevant to the complaint shall be received in evidence. The complainant, his representative, and the representatives of the agency at the hearing shall be given the opportunity to cross-examine witnesses who appear and testify. Testimony shall be under oath or affirmation.

${ }^{33} 5$ C.F.R. $\$ 771.209($ a) (1973). 
in all cases is that it is molded not by the complainant, but by the CSC. ${ }^{34}$ The complainant is allowed merely to cross-examine. ${ }^{35}$ Finally, and perhaps most important, denial of trial de novo review could undermine the strong congressional policy encouraging class action suits in cases of pervasive discrimination. ${ }^{36}$ If district courts are confined merely to review of the administrative record, those federal employees with a potentially valid class action claim who do not raise it in the administrative CSC hearing could be foreclosed from pursuing it in federal court. ${ }^{37} \mathrm{Sim}$ ilarly situated private sector employees have no such problem because they are entitled to a trial de novo. ${ }^{38}$

In the Hackley case the possible deficiencies of the CSC factual determination are well illustrated. Hackley's former supervisor had, during the course of the VA investigation, evidently "promised to write a statement that would point up why $\mathrm{Mr}$. Hackley could not expect"39 ever to be promoted. Nevertheless, the supervisor retired from government service and gave neither testimony nor any statement at the CSC hearing. ${ }^{40}$ No statistics concerning minority employment were presented at the hearing, and they were not introduced into the record until the CSC Board of Appellate Review requested them from the agency, ${ }^{41}$ even though statistics often form a vital part of

${ }^{34} 5$ C.F.R. $\$ 713.216(a)$ states in part: "The Equal Employment Opportunity Officer shall advise the Director of Equal Employment Opportunity of the acceptance of a complaint. The Director of Equal Employment Opportunity shall provide for the prompt investigation of the complaint."

${ }^{35} 5$ C.F.R. $\S 713.218$ (c)(2) (1973).

${ }^{36}$ See Jenkins v. United Gas Corp., 400 F.2d 28, 33 (5th Cir. 1968).

${ }^{37}$ In Williams v. Mumford, 6 FEP Cases 483 (D.D.C. 1973), a suit alleging racially discriminatory employment practices by the Library of Congress, plaintiffs moved to have their action certified as a class action. In denying their motion, the court noted:

There is yet a third independent ground upon which the motion to certify the class must be denied. Although the case is brought as a class action alleging across the board racially discriminatory practices through the Library, neither plaintiff raised any allegation of class discrimination in his administrative complaint of discrimination before the Library. Thus the allegations of class discrimination have not proceeded through the proper exhaustion of administrative remedies, and cannot form the basis for a class action at this time. . . . Title VII suits against federal employers are normally to be reviews of administrative action .... As such, the complaint should be limited to the allegations made at the administrative level. Id. at 486 (citations omitted).

${ }^{38}$ Nowhere in the congressional history of the Equal Employment Opportunity Act of 1972 is there any statement that the right of federal employees to bring a class suit in federal court is more restricted than the right of private employees. Indeed, there are congressional statements to the effect that the rights of federal and private sector employees were to be coextensive. See text accompanying notes 17 \& 23 supra.

${ }^{39}$ Brief for Appellant at A-53, Hackley v. Johnson, No. 73-2072, D.C. Circuit, docketed Sept. 7, 1973.

40 Id. 9.

"Id. 11 . 
Title VII litigation and have been held to establish a prima facie case of discrimination. ${ }^{42}$ Nor was there formal discovery or the taking of pretrial depositions. ${ }^{43}$

Thus, under Gardner-Denver any rule that forced election of an administrative remedy insulated from full judicial review of the factual determinations might be suspect. However, the Alexander case may not be dispositive of Hackley. In Alexander the Court denied that enforcement of Title VII should be based on the factfinding of a private arbitration proceeding. In contrast, the CSC is a public agency whose proceedings should be accorded some presumption of fairness. Congress indirectly voiced confidence in its impartiality by refusing to take from it responsibility for those claims of aggrieved federal employees who elected to use it under the Equal Employment Opportunity Act of 1972. Thus the policy analysis of the trial de novo question devolves to just how profound a presumption of correctness is to be accorded CSC factfinding. Forcing the aggrieved federal employee to elect is only undesirable if he is thereby denied a full measure of justice. The complainant should not be put in the position of trading a full and fair factual hearing for the cost savings of pursuing the administrative remedy.

\section{The Conflict of Interest Problem}

During the debates leading to the passage of the 1972 amendments to Title VII, blame for the failure to attain equal employment opportunity in the federal government was placed on the ineffective performance of the CSC. ${ }^{44}$ There were attacks on the procedure utilized in investigating and resolving discrimination allegations and on the expertise brought to bear. The House Committee on Education and Labor characterized the problem in the following manner: "The system, which permits the Civil Service Commission to sit in judgment over its own practices and procedures which themselves may raise questions of systematic discrimination, creates a built-in conflict-of-interest." 45

Members of Congress were clearly disturbed by the inherent difficulties involved in utilizing the CSC as the watchdog agency in employment discrimination matters. Its close working relationship with the other federal agencies and its responsibility over

42 See, e.g., Parham v. Southwestern Bell Tel. Co., 433 F.2d 421 (8th Cir. 1970).

${ }^{43}$ Brief for Appellant, supra note 39 , at 9.

${ }^{44}$ House Report, supra note 28, at 23-24; Senate Comm. on Labor and Pub. Welfare, Equal Employment Opportunities Enforcement ACt of 1971, S. Rep. No. 92-415, 92d Cong., 1st Sess. 14 (1971) [hereinafter cited as Senate ReporT].

${ }^{43}$ House RePort, supra note 28, at 24 (emphasis supplied); accord, Senate RePORT, supra note 44 , at 14 . 
personnel matters was recognized as being a conflict with its responsibility objectively to evaluate agency rules and procedures and non-job related employment criteria. ${ }^{46}$ Congress nevertheless decided to keep the CSC as the agency to watchdog employment discrimination in federal employment. ${ }^{47}$ At the same time however, as a safeguard, there was a provision for independent judicial action. As noted in both House and Senate reports: "An important adjunct to the strengthened Civil Service Commission responsibilities is the statutory provision of a private right of action in the courts by Federal employees who are not satisfied with the agency or Commission decision ...."48

Judicial review is especially important in the case of the CSC. There has been evidence that the CSC has been "captured" by its clientele, the federal agencies. ${ }^{49}$ "As a result, the agencies have suppressed 'whistle blowers' (responsible employees who seek to expose corruption and waste), circumvented rules on the hiring and promotion of women and minorities and, in some cases, ignored or willfully failed to carry out the tasks which Congress assigned them."50

Congressional recognition of these possible failings in CSC procedures due to conflicts of interest and the provision for judicial review of these procedures imply that the district courts should take considerable care in their review capacity. A Hackley rule absolutely denying trials de novo would limit this careful review. Without the option of mandating a trial de novo, the federal courts can only remand a case to the same imperfect factfinding procedures when a conflict or some other failing in the factual record is found. A better, more flexible, rule would be to allow a trial de novo at the court's discretion, when complainant's counsel has shown to its satisfaction the possibility of a serious prejudicial flaw in the CSC factfinding. As the House Committee on Education and Labor stated:

The Federal Service is an area where equal employment opportunity is of paramount significance. Americans rely upon the maxim 'government of the people,' and traditionally measure the quality of their democracy by the opportunity they have to participate in governmental processes. It is therefore imperative that

\footnotetext{
${ }^{46}$ House Report, supra note 28, at 24-26; SENATE Report, supra note 44, at 13-16.

4742 U.S.C. $\$ 2000$ e-16 (Supp. II, 1972).

${ }^{48}$ SENATE REPORT, supra note 44, at 15-16.

49 R. VAughn, The Spolled System (1974).

${ }^{30}$ N.Y. Times, Nov. 10, 1974, $\$ 7$ (Book Review) at 16.
} 
equal opportunity be the touchstone of the Federal system. ${ }^{51}$

To insure that equal opportunity does exist in federal government, there should be a flexible review of CSC procedures and discretionary trial de novo in federal district court.

51 House Report, supra note 28, at 22. 